\title{
Hot Isostatic Pressing Improves the Quality of the Blades from Nickel base Superalloys for Turbine Engines
}

\author{
Igor M. Razumovskii, Albert A. Tikhonov, S.F. Marinin, A.V. Logunov, \\ A.G. Beresnev \\ Joint-Stock Company “Kompozit”, 4, Pionerskaya st., Korolev, Moscow Region, 141070, \\ Russia \\ Kompozit.Mat@g23.relcom.ru
}

Key words: superalloy, hot isostatic pressing, porosity, mechanical properties.

\begin{abstract}
Typical defects of the cast engine blades from Ni base superalloys in the as-cast state and after long operation were investigated: the cast porosity, internal and external microcracs. The initial cast porosity and voids, which have appeared during long operation, reduce the fatigue and other service characteristics of the blades from Ni base superalloys. Hot isostatic pressing (HIP) reduces the size and number of micropores in the cast blades from Ni base superalloys with a polycrystalline (alloy GS6U) and single crystal (alloy GS32) structures. As a result, HIP improves the mechanical properties of the blades. Application of the HIP, together with the standard heat treatment in the renovation of the blades after long operation can provide a virtually complete restoration of their structure and efficiency.
\end{abstract}

\section{Introduction}

The cast blades from $\mathrm{Ni}$ base superalloys having an equiaxial polycrystalline, directed or single crystal structure are widely used in modern aircraft gas turbine engines. Molded blades are characterized by the presence of the casting microporosity regardless of the mode of fabrication. The main reasons for the formation of such defects are the difference between the specific volumes of liquid and solid phases and a deficit of the liquid phase at a solidification front. Application of the progressive methods of casting (directional solidification etc.) can greatly reduce the amount of micropores, but it is virtually impossible to completely eliminate them.

$\mathrm{Ni}$ base superalloys are among the classic precipitate-hardening alloys that are strengthened by $\gamma^{\prime}$ phase as the matrix precipitate $[1,2]$. Such alloys are usually subjected to the following heat treatment: a homogenization at a temperature near the solves for $\gamma$ ' phase and aging at lower temperatures in the two-phase $\left(\gamma-\gamma^{\prime}\right)$ region.

The main objective of the heat treatment of superalloys is a decrease of heterogeneity of the chemical composition caused by a dendrite structure, and a formation of the optimal $\gamma-\gamma$ ' microstructure, providing high resistance to the creep at elevated temperatures. It is obvious that a thermodynamic factor for the porosity reduces does not appear under conditions of the heat treatment of superalloys. On the contrary, the average size of micropores can increase as a result of the action of the diffusion-limited mechanism of Lifshitz-Slyozov-Wagner [3, 4].

Thus, a system of micropores of different scale is formed during crystallization of the blades that adversely impact on the performance of the blades. Indeed, the results [5] have shown that cast micropores initiate a formation of the main crack in the last stage of the creep test $\left(850^{\circ} \mathrm{C} \backslash 430 \mathrm{MPa}\right.$, single-crystals of $\mathrm{Ni}$ base superalloy, alloying system Ni-Co-W-Ta-Re-Cr-Mo$\mathrm{Al}-\mathrm{Nb}-\mathrm{Hf}$ ). That is why the problem of densification of the cast blades from Ni base superalloys as a result of reduction of the porosity is one of the most important tasks in the field of aviation materials.

Structural defects such as micropores are formed in the cast blades not only during crystallization. They also arise as a result of long service life of the blades under load at elevated temperatures $\left[6,7\right.$, and 8]. Other undesirable changes in the structure include a coagulation of the $\gamma^{\prime}$ phase particles, the violation of coherent bonds at the $\gamma / \gamma^{\prime}$ interphases, the transformation of carbides and the formation of the lamellas of TCP phases. 
Some damages of microstructure, which are accumulated in the blades during operation, one can eliminate (or minimize) by means of heat treatment. For example, using re-heat treatment of the blades as a part of the repair, one can almost restore the original $\gamma-\gamma$ ' microstructure. However operational porosity, as well as the cast pores, cannot be removed from the microstructure by means of the heat treatment technology.

The most effective way to eliminate pores of different origin from the blades is a hot isostatic pressing (HIP). Our study provides information on the impact of the HIP on the structure, mechanical properties and service characteristics of the blades from two Ni base superalloys with polycrystalline and single crystal structure.

\section{Several general principles of the HIP}

Cast blades from Ni base superalloys are fabricated in a vacuum, so the casting pores in the blades are filled with a vacuum. There are two main ways to fill the vacuum pores by the components of an alloy in a course of the HIP: i) by plastic deformation and ii) by diffusion of vacancies (vacancy dissolution of the pores). A local plastic deformation can be accumulated in the microstructure and leads to a recrystallization, which can occur either in the course of the HIP, or during of the subsequent heat treatment.

If the temperature of the HIP is located above the solvus temperature for $\gamma^{\prime}$ phase, where the particles of $\gamma^{\prime}$ phase are dissolved, the probability of the recrystallization in a course of the HIP increases. If the temperature of the HIP is located below the solvus temperature for $\gamma^{\prime}$ phase, i.e. the HIP is carried out in two-phase $\left(\gamma-\gamma^{\prime}\right)$ area, the particles of the hardening $\gamma^{\prime}$ phase can prevent the recrystallization in a course of the HIP. In this case, the recrystallization may occur during subsequent heat treatment (at a stage of homogenization).

Thus, in order to deter from the recrystallization, one has to minimize plastic deformation in a course of the HIP by means of a choice of the optimal HIP parameters (temperature, pressure, time). A suppression of the recrystallization is particularly important for the single crystals of $\mathrm{Ni}$ base superalloys, since an appearance of the new grains means a destruction of the single crystal structure. To estimate an efficiency of the diffusion-limited process of the pore's dissolution one can use the diffusion data for $\mathrm{Ni}$ base superalloys (see, for example [9]). We believe that a diffusion-limited mechanism of the pore's dissolution is more favorable than the deformation mode independently of the blade's structure (poly - or single crystal). The recrystallization in a course of the HIP is an undesirable phenomenon in the polycrystals too because the boundaries of the new grains can be weakened as compared with the boundaries of "the old" grains.

\section{HIP of cast blades with polycrystalline and single crystal structure. As-cast state}

We investigated the effect of HIP on the porosity and mechanical properties of the cast specimens and blades using Ni-base superalloy GS6U $(\mathrm{Ni}+8,8 \mathrm{Cr}+9,8 \mathrm{Co}+1,8 \mathrm{Mo}+10,3 \mathrm{~W}+5,6 \mathrm{Al}+2,4 \mathrm{Ti}$ $+1,0 \mathrm{Nb}+0,17 \mathrm{C}$, wt.\%) [10] with a polycrystalline structure and Ni-base superalloy GS32 (Ni $+4,9$ $\mathrm{Cr}+9,0 \mathrm{Co}+1,0 \mathrm{Mo}+8,5 \mathrm{~W}+5,9 \mathrm{Al}+1,6 \mathrm{Nb}+4,0 \mathrm{Ta}+4,0 \mathrm{Re}+0,02 \mathrm{~B}+0,15 \mathrm{C}$, wt.\%) [10] with a single crystal structure. HIP of the samples and blades was carried out using equipment with the following operating parameters: the temperature up to $2000^{\circ} \mathrm{C}$, the pressure of high purity argon up to $200 \mathrm{MPa}$.

The results of metallographic investigation of the porosity of the blades in the as-cast state are given in Table 1.

Table 1 demonstrates that the average and maximum pore size in both alloys significantly decreases as a result of the HIP and the total number of the pores decreases 10 - 30 times. 
Table 1. The size and number of the pores in the blades before and after the HIP.

\begin{tabular}{|c|c|c|c|c|}
\hline Superalloy & $\begin{array}{c}\text { State of the } \\
\text { blades }\end{array}$ & $\begin{array}{c}\text { Mean size of the } \\
\text { pores, } \mathrm{mkm}\end{array}$ & $\begin{array}{c}\text { Maximum size of } \\
\text { the pores, } \mathrm{mkm}\end{array}$ & $\begin{array}{c}\text { The total } \\
\text { number, } \%\end{array}$ \\
\hline \multirow{2}{*}{$\begin{array}{c}\text { GS6U } \\
\text { Polycrystal }\end{array}$} & Before HIP & 19,7 & 80,1 & 0,68 \\
\cline { 2 - 5 } Gingle crystal & After HIP & 3,8 & 4,8 & 0,07 \\
\cline { 2 - 5 } GS32 & Before HIP & 14,7 & 53,8 & 0,33 \\
\hline \multicolumn{2}{|r}{} & 3,1 & 4,6 & 0,01 \\
\hline
\end{tabular}

The typical form of micropores in the cast blades before the HIP is shown in Figure 1.

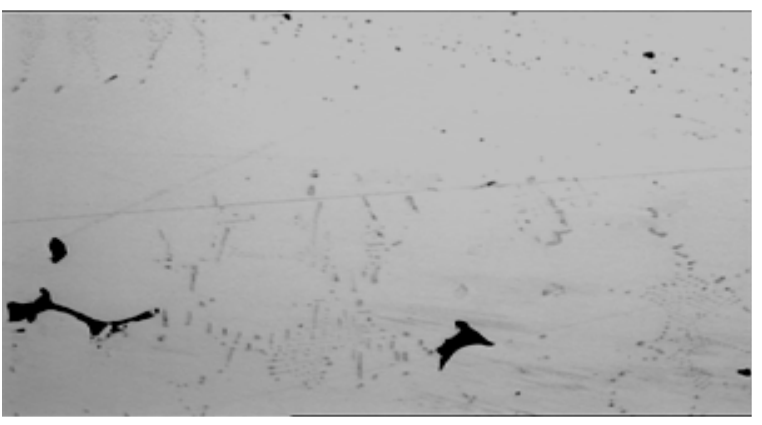

(a)

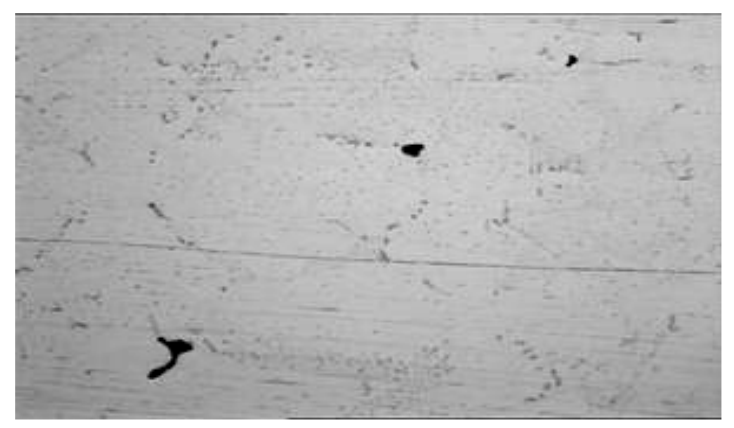

(b)

Fig.1. Micropores in the cast blades of alloys GS6U (a) and GS32 (b) before the HIP. Microstructure without etching. x 250.

It should be noted that the microstructure of the single-crystal blades of alloy GS32 after the HIP did not reveal the recrystallization.

An influence of the HIP on the mechanical properties of the superalloys was evaluated by testing cylindrical samples with polycrystalline (alloy GS6U) and single-crystal (alloy GS32, growth axis $\langle 100>$ ) structure. All castings before fabricating the samples were subjected to the standard heat treatment (HT). The results of short-term testing of the mechanical properties are listed in Table 2.

Table 2. The mechanical properties of the superalloys GS6U and GS32 at room temperature.

\begin{tabular}{|l|c|c|c|}
\hline \multicolumn{1}{|c|}{ Property } & State of samples & $\begin{array}{c}\text { Superalloy GS6U } \\
\text { (polycrystal) }\end{array}$ & $\begin{array}{c}\text { Superalloy GS32 } \\
\text { (single crystal) }\end{array}$ \\
\hline Tensile strength, $\sigma_{\mathrm{b}}, \mathrm{MPa}$ & Cast+HT & $855-917$ & $1016-1118$ \\
\cline { 2 - 4 } & Cast+HIP+HT & $1049-1112$ & $1148-1187$ \\
\hline \multirow{2}{*}{ Yield strength, $\sigma_{0,2}, \mathrm{MPa}$} & Cast+HT & $765-814$ & $895-956$ \\
\cline { 2 - 4 } & Cast+HIP+HT & $895-930$ & $960-972$ \\
\hline Elongation $\delta, \%$ & Cast+HT & $3-6$ & $7-8$ \\
\cline { 2 - 4 } & Cast+HIP+HT & $7-8$ & $10-20$ \\
\hline
\end{tabular}

The time-to-rupture for the superalloy GS6U samples at $975^{\circ} \mathrm{C}$ under $225 \mathrm{MPa}$ was increased from 48-62 hours to 58-96 hours as a result of the HIP; for the superalloy GS32 tested at $1000^{\circ} \mathrm{C}$ under $245 \mathrm{MPa}$, the time-to-rupture increased from 139-186 hours to $190-229$ hours after the HIP.

The HIP results in remarkably high mechanical fatigue properties of the blades. The high cycle fatigue (HCF) strength of the blades from GS6U (to $2 \times 10^{7}$ cycles $\mathrm{N}_{\mathrm{f}}$ ) is improved from 160$180 \mathrm{MPa}$ to $190-220 \mathrm{MPa}$ by HIP. The HCF strength of the blades from GS32 (to $2 \times 10^{7}$ cycles $\mathrm{N}_{\mathrm{f}}$ ) is improved from 130-150 MPa to $190-210 \mathrm{MPa}$ by HIP. 


\section{Using HIP for repair of the blades after operation}

The generally accepted repair treatment of the blades after operation is a full heat treatment and application of a new protective coating.

Our results $[6,7$, and 8$]$ show that the HIP can be useful addition to the common technology of repair of the blades after operation. At present we studied the blades from GS6U after operation during 2,369; 4,957 and 10,875 hours. The blades under investigation were subjected to the HIP and the complete cycle of heat treatment.

Metallographic investigation of the porosity of the blades with different operation ages before and after the HIP was performed on thin sections of the blades cut at the distance of $20 \mathrm{~mm}$ from their base. The most characteristic forms of the micropores are shown in Fig. 2.

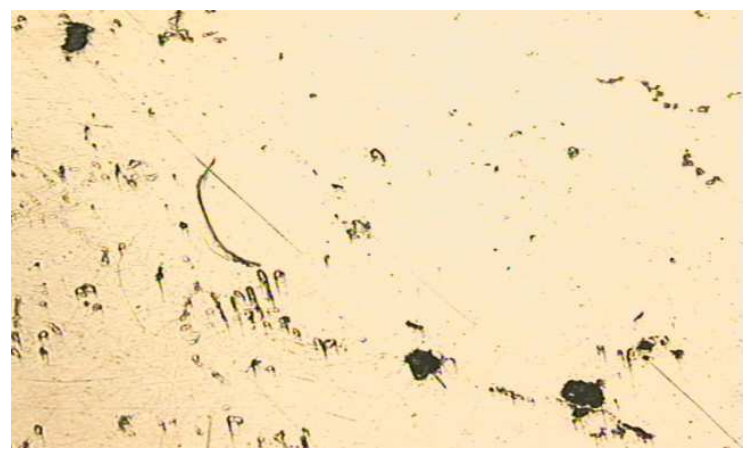

(a)

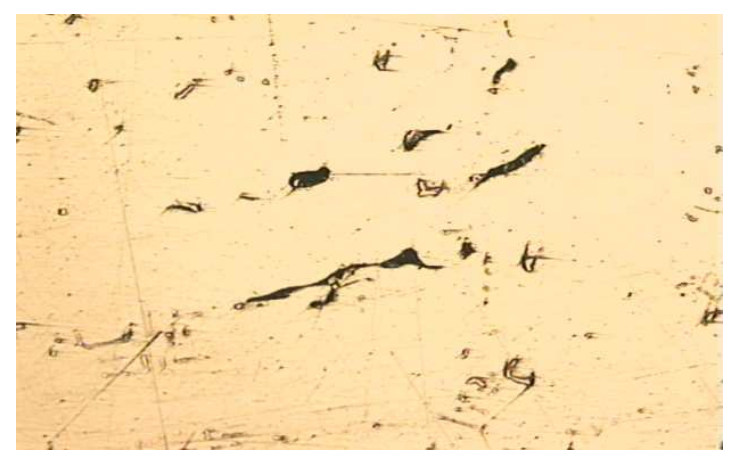

(b)

Fig.2 Micropores in the cast blades from alloy GS6U after operation ages 4,957 hours (a) and 10,875 hours (b). x 250 .

The results of metallographic analysis of the porosity of the blades in different states are given in Table 3.

Table 3. The size and number of the pores in the operated blades before ${ }^{*}$ and after the HIP.

\begin{tabular}{|c|c|c|c|c|}
\hline $\begin{array}{c}\text { Time of } \\
\text { operation, hours }\end{array}$ & $\begin{array}{c}\text { State of the } \\
\text { blades }\end{array}$ & $\begin{array}{c}\text { Mean size of the } \\
\text { pores, } \mathrm{mkm}\end{array}$ & $\begin{array}{c}\text { Maximum size of } \\
\text { the pores, mkm }\end{array}$ & $\begin{array}{c}\text { The total } \\
\text { quantity, \% }\end{array}$ \\
\hline \multirow{2}{*}{2,369} & Before HIP & 5,2 & 28,1 & 0,2 \\
\cline { 2 - 5 } & After HIP & 3,1 & 5,1 & 0,1 \\
\hline \multirow{2}{*}{4,957} & Before HIP & 11,1 & 51,5 & 0,68 \\
\cline { 2 - 5 } & After HIP & 3,2 & 11,3 & 0,12 \\
\hline \multirow{2}{*}{10,875} & Before HIP & 10,7 & 68,4 & 0,84 \\
\cline { 2 - 5 } & After HIP & 3,4 & 16,2 & 0,12 \\
\hline
\end{tabular}

$\left.{ }^{*}\right)$ Note. Before re-treatment HIP: blades in the initial state (as-cast) have been subjected to the HIP and heat treatment. For comparison with the original state one has to use the data of Table 1 .

Table 3 shows that the maximum pore size is decreased by 4-6 times, the total number of the pores is reduced in 2-7 times by HIP. HIP can recover the characteristics of the pores in the blades after 2,369 operation hours almost to their initial characteristics (see Table 1 for comparison).

HIP + heat treatment almost completely restores the fatigue characteristics of the operated blades (after 2,369 hours, $\sigma_{-1}{ }^{\text {oper }} \backslash \sigma_{-1}{ }^{\text {init }}=0.96$; after 4,957 hours, $\sigma_{-1}{ }^{\text {open }} \backslash \sigma_{-1}{ }^{\text {init }}=0.91$ ), Table 4 . 
Table 4. Recovery of the fatigue properties of the blades from GS6U by means of the heat treatment (HT) and HIP.

\begin{tabular}{|c|c|c|c|}
\hline Property & $\begin{array}{c}\text { The operation time, } \\
\text { hours }\end{array}$ & State of the blades & $\sigma_{-1}, \mathrm{MPa}$ \\
\hline \multirow{6}{*}{$\begin{array}{l}\text { High-cycle fatique } \\
\left(2 \times 10^{7} \text { cycles }\right), \sigma_{-1}, \mathrm{MPa}\end{array}$} & \multirow{2}{*}{$\begin{array}{c}0 \\
\text { (initial state) }\end{array}$} & HT (without HIP) & $157-187$ \\
\hline & & HT+HIP & $197-215$ \\
\hline & \multirow[t]{2}{*}{2,369} & HT (without HIP) & $157-176$ \\
\hline & & $\mathrm{HT}+\mathrm{HIP}$ & $186-206$ \\
\hline & \multirow[t]{2}{*}{4,957} & HT (without HIP) & $138-157$ \\
\hline & & $\mathrm{HT}+\mathrm{HIP}$ & $176-196$ \\
\hline
\end{tabular}

Note. Tested 5-6 blades of each state.

A long service life of the blades at high temperatures under loads causes not only a formation of the new pores (the operational porosity), but also leads to the complex changes in the structure, phase and chemical composition. This paper deals with the porosity and its influence on the mechanical properties of superalloys. We note here only one important observation concerning the structure: the service life of the blades from GS6U alloy for 10,875 hours causes the formation of the carbide colonies, especially in the surface areas of the blades, Fig. 3, which cannot be removed using the HIP and heat treatment.

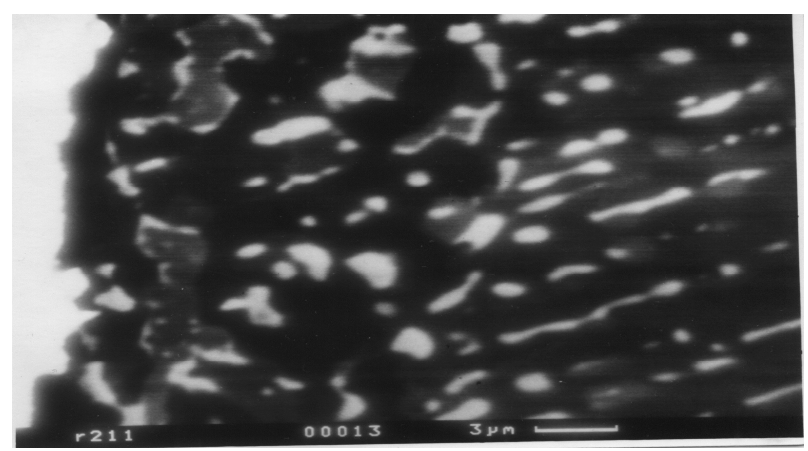

a)

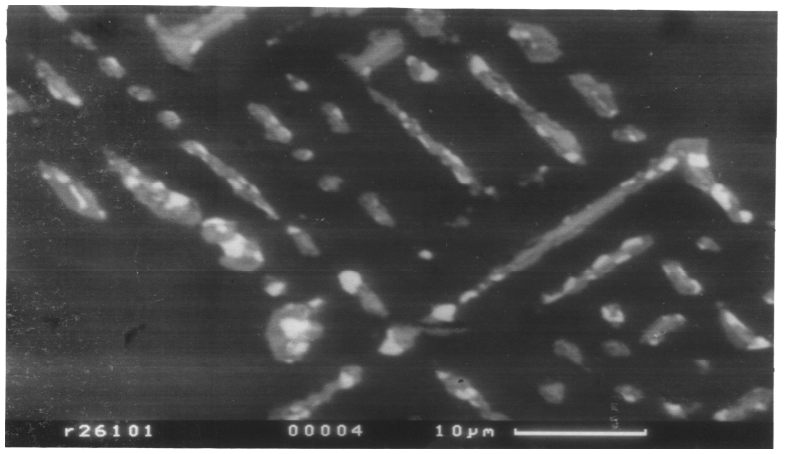

6)

Fig.3 Carbide colonies near the outer surface (a) and in the depth of the blade (b) with the service life of 10,875 hours.

The regimes of the HIP, that were developed by JSC "Komposite" to treat castings from Ni base superalloys with polycrystalline and single crystal structure and for the repair of the blades after long service life can be found in the patents of RF №№ 2309191, 2346799 and 2380454.

\section{Conclusions}

1. Hot isostatic pressing reduces the size and number of micropores in the cast blades from Ni base superalloys with a polycrystalline (alloy GS6U) and single crystal (alloy GS32) structures. As a result, HIP improves the mechanical properties of the blades.

2. Application of the HIP, together with a standard heat treatment in the renovation of the blades after their operation can provide a virtually complete restoration of their structure and efficiency. 


\section{References}

1. J.-L. Strudel. Mechanical properties of multiphase alloys. In: Physical metallurgy, Ed. by R.W. Cahn and P. Haasen, vol. III, the Netherlands, Elsevier Science (1996) p. 2147.

2. B.A. Kolachev, V.I. Elagin and V.I. Livanov. Metallovedenie i termicheskaya obrabotka cvetnyh metallov i splavov. Moscow: MISIS (2005) 328 p.

3. I.M. Lifshitz, V.V. Slyozov. J. Phys. Chem. Solids 19 (1961) 35.

4. C. Wagner. Z. Elektrochemie 65 (1961) 581.

5. Q.Z. Chen, N. Jones, D.M. Knowles. Acta Materialia 50 (2002) 1095.

6. A.V. Logunov, V.I. Golovanov, I.M. Razumovskii, S.F. Marinin, A.A. Tikhonov, V.A. Poklad, V.S. Frolov, Y.G. Bykov. Perspectivnye materialy 3 (2004) 12.

7. S.F. Marinin, A.A. Tikhonov, A.A. Logunov, I.M. Razumovskii, V.I. Golovanov. Proc. 4d Moscow Int. Conf. on " Teoriya i praktika tehnology proizvodstva izdely iz kompozicionnyh i novyh metallicheskih materialov“. Moscow, Znanie (2006) 388.

8. A.A. Tikhonov, S.F. Marinin, A.V. Logunov, I.M. Razumovskii, A.I. Vinogradov, V.A. Kochetkov. Proc. 5th Moscow Int. Conf. on "Teoriya i praktika tehnology proizvodstva izdely iz kompozicionnyh i novyh metallicheskih materialov". Moscow, Znanie (2008) 311.

9. S.Z. Bokstein, S.S. Ginzburg, S.T. Kishkin, I.M. Razumovskii, G.B. Stroganov. Avtoradiografiya poverkhnostei razdela i strukturnaya stabil'nost' splavov (Autoradiography of interphases and structural stability of alloys). Moscow: Metallyrgiya (1987) 272 pp.

10. Enciklopediya "Mashinostroenie". V. II-3 "Tsvetnye metally i splavy. Kompozicionnye metallicheskie materialy". Moscow: Mashinostroenie (2001) 536. 